\section{Bigtooth Maples from Selected Provenances Effectively Endure Deficit Irrigation}

\author{
Emad Bsoul and Rolston St. Hilaire ${ }^{1}$ \\ Department of Plant and Environmental Sciences, New Mexico State \\ University, Box 30003, Las Cruces, NM 88003
}

Dawn M. VanLeeuwen

Agricultural Biometric Service, New Mexico State University, Box 30003, Las Cruces, NM 88003

Additional index words. Acer grandidentatum, carbon isotope discrimination, woody ornamentals, water relations

\begin{abstract}
Although bigtooth maple (Acer grandidentatum Nutt.) is an ornamental plant that might thrive in managed landscapes in arid and semiarid regions, little information on the drought tolerance of bigtooth maples appears to be available. We studied water relations, plant development, and carbon isotope composition of bigtooth maples indigenous to New Mexico, Texas, and Utah that were field-grown in New Mexico using a pot-in-pot nursery production system. Plants were maintained as well-irrigated controls or irrigated after the weight of pots decreased by $35 \%$ due to evapotranspiration. Bigtooth maples subjected to drought had more negative predawn leaf water potentials $(-0.76 \mathrm{MPa})$ than the plants in the control treatment $(-0.64 \mathrm{MPa})$. Drought did not affect midday leaf water potential of seed sources. Trees native to the Lost Maples State Natural Area in Vanderpool, TX (designated LMP5), had the greatest leaf area $\left(1236 \mathrm{~cm}^{2}\right)$ among plants from all sources, while those native to Logan Canyon in Cache County, UT (designated UW2), had among the smallest leaf area $\left(216 \mathrm{~cm}^{2}\right)$. Leaf area ratio (LAR) was highest in plants from LMP5 $\left(24.23 \mathrm{~cm}^{2} \cdot \mathrm{g}^{-1}\right)$, which suggests that they have potential for more carbon assimilation than the other plants tested. Plants from LMP5 had the highest leaf area/xylem diameter ratio $\left(135 \mathrm{~cm}^{-2} \cdot \mathrm{mm}^{-1}\right)$. This ratio was 5.8 times higher than that of UW2, which had among the lowest leaf area/xylem diameter ratios. The high leaf area/xylem diameter ratio of LMP5 plants relative to UW2 plants indicates that LMP5 plants had a larger surface area of tissues that transpire relative to those that transport water. Treatment did not affect stomatal conductance $\left(g_{\mathrm{S}}\right)$ or transpiration, but $g_{S}$ and transpiration were positively correlated for both droughtstressed $\left(r^{2}=0.801\right)$ and well-irrigated plants $\left(r^{2}=0.759\right)$. Plants from New Mexico (designated DS) had the lowest transpiration rate $\left(2.32 \mathrm{mmol} \cdot \mathrm{m}^{-2} \cdot \mathrm{s}^{-1}\right)$, lowest $g_{\mathrm{s}}(52.1$ $\left.\mathrm{mmol} \cdot \mathrm{m}^{-2} \cdot \mathrm{s}^{-1}\right)$, largest xylem diameter $(11 \mathrm{~mm})$, and had among the largest shoot dry weight (DW) and plant height. Plants did not differ either among sources or between treatments in the ratio of variable to maximal fluorescence $($ mean $=0.64)$, relative water content (averaged 57\%), specific leaf weight, stem DW, root DW, and plant DW. Carbon isotope discrimination $(\Delta)$ averaged $-26.53 \%$ and did not differ among plant sources or irrigation treatments. This suggests that $\Delta$ might not be effective in screening bigtooth maples for drought tolerance. Low transpiration rate, $g_{s}$, and high shoot dry weight in DS plants and traits, such as a high LAR in plants from LMP5, suggest that plants selected from these provenances might effectively endure deficit irrigation.
\end{abstract}

Arid and semiarid regions constitute one third of the world's land type (Batisse, 1994), making it the world's largest ecosystem. Selecting plant ecotypes adapted to these regions will be important for the world's natural and managed landscapes. One strategy that might be effective in selecting plants for arid and semiarid regions is to identify

Received for publication 30 May 2006. Accepted for publication 17 Aug. 2006.

Contribution of the N.M. Agricultural Experiment Station, N.M. State Univ., Las Cruces.

${ }^{1}$ To whom reprint requests should be addressed; e-mail rsthilai@nmsu.edu grandidentatum Nutt.) is a candidate taxon for selecting drought-tolerant ecotypes.

Plant water relations (Hsiao, 1973), stable carbon isotope discrimination (Ehleringer et al., 1993; Farquhar et al., 1989), and chlorophyll fluorescence (Feser et al., 2005; Percival and Sheriffs, 2002) are physiological attributes that delineate the fitness of a plant for drought. Predawn stem or leaf water potential is a common indicator of drought stress and water status in a plant (Fort et al., 1997; Peuke et al., 2002) because it is a measure of energy within the leaf or stem when transpiration and photosynthesis is minimal (Abrams and Knapp, 1986). When the plant is transpiring and photosynthesizing, stem water potential can be used to compare energy levels within a plant species. Stem water potential of bigtooth maples growing in Big Cottonwood Canyon in the Wasatch Mountains of Utah varied with altitude (Dina et al., 1973). The lack of a strong correlation of vapor pressure deficit with water potential in bigtooth maples relative to that of Cercocarpus ledifolius and Berberis repens led Dina et al. (1973) to suggest that bigtooth maple stomata are less sensitive to water potential variation than either $C$. ledifolius or B. repens. The impact of vapor deficits might have been less in bigtooth maples because of their larger stature and deeper and more extensive root systems compared with $C$. ledifolius or B. repens. So, knowledge of both the stomatal behavior and water potential during moisture stress is critical to the understanding of bigtooth maple physiology during drought.

Stable carbon isotope discrimination $(\Delta)$ of leaves reflects the ratio of leaf internal to external $\mathrm{CO}_{2}$ concentration $\left(C_{\mathrm{i}} / C_{\mathrm{a}}\right)$ and is an integrated long-term measure of factors affecting leaf conductance and photosynthetic rate (Farquhar et al., 1989; Farquhar and Lloyd, 1993). Zhang and Marshall (1994) showed that $\Delta$ of western larch (Larix occidentalis Nutt.) seedlings correlated with transpiration efficiency $(r=-0.85)$ and instantaneous water use efficiency $(r=$ $-0.70)$. How $\Delta$ might be used as a selection criterion for bigtooth maple plants that might be planted in drought-prone environments is unknown. In red maples (Acer rubrum L.), Bauerle et al. (2003) found no differences in $\Delta$ between wet-site and dry-site provenances.

Drought might cause a lower $C_{\mathrm{i}} / C_{\mathrm{a}}$ if leaf conductance decreases at a faster rate under stress than the photosynthetic demand for $C_{\mathrm{i}}$. Under such conditions, $\Delta$ might not accurately reflect carbon assimilation (Major and Johnsen, 1996). So, analysis of $\Delta$ as a measure of fitness under drought should be done in conjunction with other physiological parameters (Major and Johnsen, 1996), such as chlorophyll fluorescence. Dark-adapted values of ratio of variable to maximal fluorescence $\left(F_{\mathrm{v}} / F_{\mathrm{m}}\right)$ reflect the potential photochemical efficiency of PSII (Björkman and Demming, 1987; Demming-Adams and Adams, 1992). Although decreases in $F_{\mathrm{v}} / F_{\mathrm{m}}$ have been related to photoinhibitory damage of the photosynthetic apparatus 
(Demming-Adams and Adams, 1992), Baz and Fernandez (2002) noted that chlorophyll fluorescence is usually affected only after severe drought.

Species of maple that have been recommended for landscape use in the arid and semiarid regions of the southwestern United States are Acer barbatum Michx. (southern sugar maple), Acer glabrum Torr. (Rocky Mountain maple), Acer grandidentatum Nutt. (bigtooth maple), Acer leucoderme Small (chalk maple), Acer negundo L. (box elder), Acer nigrum Michx. f., and Acer rubrum L. (red maple) (Simpson and Hipp, 1993). Of those taxa, several horticulturists agree that bigtooth maple warrant more use in southwestern landscapes (Barker, 1974; St. Hilaire, 2002; Tankersley, 1981). Ecological attributes of bigtooth maples, such as cold hardiness to $-40^{\circ} \mathrm{C}$, tolerance to multiple soil conditions, and existence on both mesic and xeric sites suggest that it might be planted in many areas of North America (Barker, 1974, 1975; St. Hilaire, 2002). However, bigtooth maples remain relatively scarce in managed landscapes of the southwestern United States (St. Hilaire, 2002). We gathered preliminary evidence that bigtooth maples originating in New Mexico, Texas, and Utah might be resilient to drought (Bsoul et al., 2006). For example, bigtooth maple plants originating from Lost Maples State Natural Area in Vanderpool, TX, maintained similar predawn water potentials between drought-stressed and control plants after five cycles of drought. Bigtooth maples from New Mexico exposed to drought had high net assimilation rates and relative growth rates, while those from selected provenances in Utah had high leaf area ratios (Bsoul et al., 2006).

Our objective was to compare drought responses of bigtooth maples indigenous to locations in Texas, New Mexico, and Utah using an in-ground (pot-in-pot) nursery production system. Some of the selected seed sources in each location included semiarid and arid regions, so we hypothesized that differences in drought responses in plants from all sources might reveal drought-tolerant ecotypes. Our approach was to measure growth and developmental traits, water relations, photochemical efficiency, stable carbon isotope discrimination, and foliar carbon and nitrogen contents to evaluate responses of bigtooth maples exposed to drought.

\section{Materials and Methods}

Plant material. Plants were selected from 2-year-old seedlings of bigtooth maples collected from several seed sources that were maintained in a greenhouse collection at New

Table 1. Seed source, growth characteristics, and biomass allocation patterns of five seed sources of bigtooth maples (A. grandidentatum) harvested on 23 Aug. 2003, the day drought treatments started.

\begin{tabular}{llcccc}
\hline Seed source & $\begin{array}{c}\text { Tree } \\
\text { code }\end{array}$ & $\begin{array}{c}\text { Plant ht } \\
(\mathrm{cm})\end{array}$ & $\begin{array}{c}\text { Shoot dry } \\
\text { wt }(\mathrm{g})\end{array}$ & $\begin{array}{c}\text { Root/shoot dry } \\
\text { wt ratio }(\mathrm{g} / \mathrm{g})\end{array}$ & $\begin{array}{c}\text { Leaf area/xylem } \\
\text { diam }\left(\mathrm{cm}^{-2} \cdot \mathrm{mm}^{-1}\right)\end{array}$ \\
\hline $\begin{array}{l}\text { Dripping Springs } \\
\quad \text { State Park, Las Cruces, NM }\end{array}$ & DS & $66 \mathrm{a}^{\mathrm{z}}$ & $34 \mathrm{a}$ & $1.02 \mathrm{~b}$ & $1404 \mathrm{a}$ \\
$\begin{array}{l}\text { Guadalupe Mountains, } \\
\quad \text { Salt Flat, TX }\end{array}$ & GM2 & $66 \mathrm{a}$ & $34 \mathrm{a}$ & $0.74 \mathrm{bc}$ & $147 \mathrm{a}$ \\
$\begin{array}{l}\text { Lost Maples State Natural } \\
\quad \text { area, Vanderpool, TX }\end{array}$ & LMP1 & $81 \mathrm{a}$ & $38 \mathrm{a}$ & $0.49 \mathrm{c}$ & $139 \mathrm{a}$ \\
$\begin{array}{l}\text { Logan Canyon, } \\
\quad \text { Cache County, UT }\end{array}$ & UW2 & $40 \mathrm{a}$ & $50 \mathrm{a}$ & $0.50 \mathrm{c}$ & $989 \mathrm{a}$ \\
$\begin{array}{l}\text { Means } \\
P \text { value }\end{array}$ & & 66 & $12 \mathrm{~b}$ & $1.43 \mathrm{a}$ & $66 \mathrm{a}$ \\
\hline
\end{tabular}

$\overline{\mathrm{z}_{\mathrm{LSM}}(n=4) \text { within columns sharing the same letter do not differ statistically. LSM differences were assessed }}$ at $P \leq 0.05$ using the Proc Mixed/PDIFF option in SAS/STAT 9.1 (2004).
Mexico State University. Seed sources originated from the following locations: Logan Canyon, Cache County, UT (elevation 2300 $\mathrm{m}$, lat. $41^{\circ} 46^{\prime} 00^{\prime \prime} \mathrm{N}$; long. $111^{\circ} 49^{\prime} 00^{\prime \prime} \mathrm{W}$ ), Dripping Springs State Park, Las Cruces, NM (elevation $1280 \mathrm{~m}$, lat. $32^{\circ} 23^{\prime} 20^{\prime \prime} \mathrm{N}$; long. $\left.106^{\circ} 48^{\prime} 47^{\prime \prime} \mathrm{W}\right)$, Guadalupe Mountains, Salt Flat, TX (elevation $1680 \mathrm{~m}$, lat. $31^{\circ} 54^{\prime} 00^{\prime \prime} \mathrm{N}$; long. $104^{\circ} 52^{\prime} 01^{\prime \prime} \mathrm{W}$ ). Two seed sources originated from Lost Maples State Natural Area, Vanderpool, TX (elevation $580 \mathrm{~m}$, lat. $29^{\circ} 40^{\prime} 00^{\prime \prime} \mathrm{N}$; long. $99^{\circ} 21^{\prime} 00^{\prime \prime} \mathrm{W}$ ). These five seed sources were assigned letter codes to identify the single-tree origin of the seeds (Table 1).

Plants were maintained in the greenhouse and received irrigation every $7 \mathrm{~d}$ with a fertilizer solution ( $\mathrm{pH} 7.3$ and EC $1.2 \mathrm{dS} \cdot \mathrm{m}^{-1}$ ) containing $\mathrm{N}$ at $150 \mathrm{mg} \cdot \mathrm{L}^{-1}$ from a mixture (1:1 by weight) of Peters Excel (15N-2.2P$12.5 \mathrm{~K})$, and Peters Professional (20N-4.4P$16.6 \mathrm{~K}$ ) fertilizers (Scotts, Marysville, $\mathrm{OH}$ ). From 15 Dec. 2002, to 2 Mar. 2003, dormant plants were irrigated with the fertilizer solution every 14 d. On 3 Mar. 2003, plants were moved to an open-sided lath house providing $35 \%$ overhead shade to acclimate to outdoor conditions. On 30 Mar., the dormant seedlings were transferred from their $15-\mathrm{L}$ pots and potted into $30-\mathrm{L}$ (height $=36 \mathrm{~cm}$; top diameter $=117 \mathrm{~cm}$, and bottom diameter $=$ $107 \mathrm{~cm}$ ) plastic pots containing a mixture of peatmoss and perlite (1:1, by volume). Screens placed at the bottom of the pots retained the growing substrate. Air-filled porosity of the growing substrate was $28 \%$, and water-holding capacity was $37 \%$ as determined by procedures of Handreck and Black (2002). Moisture-release curves showed that moisture was released from the medium at suction pressure of up to 0.70 $\mathrm{MPa}$. The medium was at field capacity at 0.1 $\mathrm{MPa}$. Plants were then irrigated with tap water every $3 \mathrm{~d}$ until 30 Apr. and every other day until the start of the experiment.

Environmental conditions and experimental design. The experiment was conducted in a field at the Fabian Garcia

Table 2. Growth and development traits of five seed sources of bigtooth maple seedlings harvested after $81 \mathrm{~d}$ of drought treatment. ${ }^{\mathrm{z}}$

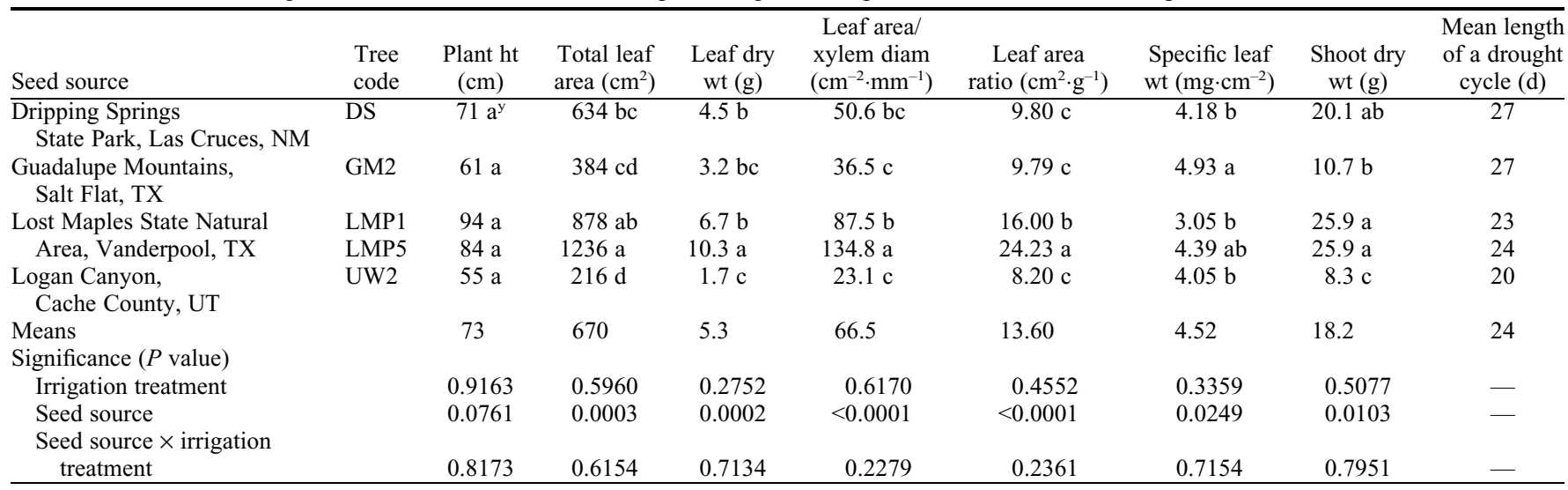

${ }^{2}$ Drought treatments were initiated on 23 Aug. 2003. Plants in the control treatment were irrigated every other day. Each seed source completed three drought cycles, and the mean length of each drought cycle is given.

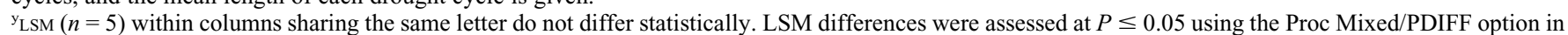
SAS/STAT 9.1 (2004). 

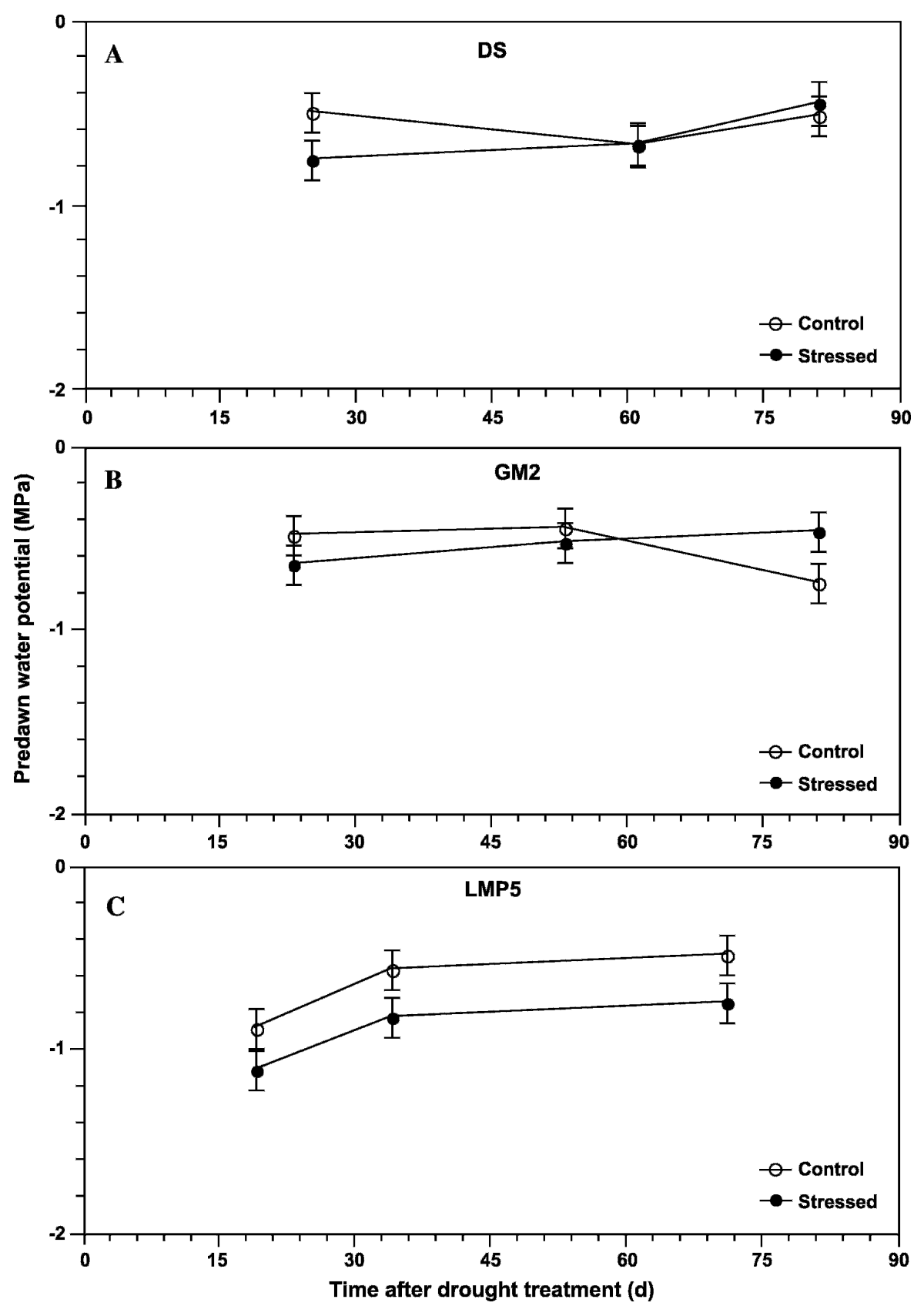

Fig. 1. Predawn water potential of plants from three seed sources of $A$. grandidentatum (bigtooth maple) subjected to $81 \mathrm{~d}$ of cyclic drought. Plants from each seed source completed three drought cycles. (A) DS, one seed source from Dripping Springs State Park, Las Cruces, NM; (B) GM2, one seed source from the Guadalupe Mountains, Salt Flat, TX; and (C) LMP5, one seed source from Lost Maples State Natural Area, Vanderpool, TX. Because there were only two measurement days for LMP1 and UW2, these graphs are not shown. Each point represents a mean $\pm \mathrm{SE}(n=5)$.

Science Center at New Mexico State University (elevation $1183 \mathrm{~m}$; lat. $32^{\circ} 16^{\prime} \mathrm{N}$, long. $106^{\circ} 46^{\prime} \mathrm{W}$ ) using an in-ground nursery production system with sufficient subsurface drainage to ensure water drained freely from the containers. Pots were spaced $1.3 \mathrm{~m}$ between and within rows. A $1.5-\mathrm{m}$ walkway was used to separate each of the five blocks used in study. The surface among the pots was bare native Glendale clay soil (USDA Soil Conservation Service, 1980).

During the experimental period (23 Aug. to 11 Nov. 2003), mean midday $P P F$ density measured with a quantum sensor (LI200S control). The experimental design was a randomized complete block with seven blocks, five seed sources, and two irrigation treatments.

Initial seedling traits. On 23 Aug. 2003, irrigation treatments were initiated. On that day, two plants from each source in each of two blocks (four plants) were harvested destructively to determine initial seedling growth characteristics. Lamina surface area of leaves $\geq 2 \mathrm{~cm}$ long was measured with a leaf area meter (LI-3000A; LICOR). Plant height was then recorded as the length of stem from the growing substrate to uppermost bud. Xylem diameter was measured at $1 \mathrm{~cm}$ above the stem base after the bark was peeled back. Roots were washed with water to dislodge growing substrate $2 \mathrm{~d}$ after severance of stems. Weights of leaves, stems, and washed roots were determined after drying for $5 \mathrm{~d}$ at $65{ }^{\circ} \mathrm{C}$. Five blocks were retained to determine plant responses during and after exposure to drought.

Drought treatment. When drought treatments started, all plants were hand irrigated to saturation with the fertilizer solution. For each source, three of the five plants assigned to drought were chosen randomly to indicate the end of the drought cycle. Indicator plants were allowed to drain for $2 \mathrm{~h}$ and then weighed. Plants were weighed between 1100 and 1200 HR. Subsequently, irrigation was withheld from plants in the drought treatment. No water was applied to pots during irrigation treatments. Furthermore, we did not construct rain shelters for the plants. During the experimental period, nine rainfall events averaged $2.3 \mathrm{~mm}$ per event A drought cycle for each seed source ended when the combined weight of the indicator pots decreased by $35 \%$ due to evapotranspiration (ET). All plants completed three drought cycles, and the mean length of a drought cycle averaged $24 \mathrm{~d}$ (Table 2). Drought treatments started on 23 Aug. and ended on 11 Nov. 2003. Preliminary experiments with three plant sources showed that $35 \%$ moisture loss due to ET was severe enough to cause plant wilting but not mortality. At the end of each drought cycle, volumetric moisture content of the upper 6 $\mathrm{cm}$ of the growing substrate was determined with a theta probe (type HH1; Delta-T Devices, Cambridge, U.K.) set on the organic option. Volumetric water content averaged $0.101 \pm 0.007 \mathrm{~m}^{3} \cdot \mathrm{m}^{-3}$ in droughted plants and $0.353 \pm 0.007 \mathrm{~m}^{3} \cdot \mathrm{m}^{-3}$ in control plants. Control plants were irrigated every other day with an automatic drip irrigation system. Drip emitters were rated at $7.5 \mathrm{~L} /$ hour, and the irrigation system was scheduled for $60 \mathrm{~min}$ every other day. Leaching fraction from irrigated pots averaged $20 \%$.

Chlorophyll fluorescence. At the end of each drought cycle, irrigation was withheld from plants until the next day. Between 1130 and $1300 \mathrm{HR}$ on the same day that the drought cycle ended, the ratio of variable to maximal fluorescence $\left(F_{\mathrm{v}} / F_{\mathrm{m}}\right)$ was measured from the youngest fully expanded leaf on all plants Leaves were dark-adapted by attaching a 
dark adaptation clip (Product FL-DC, Opti-Sciences, Tyngsboro, MA) to the interveinal region of a fully expanded leaf for 30 minutes. Measurements were recorded using a continuous source fluorometer (OS-30; Opti-Sciences). Fluorometer excitation source intensity was set at $3000 \mu \mathrm{mol} \cdot \mathrm{m}^{-2} \cdot \mathrm{s}^{-1}$ for 2 seconds.

Plant water relations. At predawn $(0330$ to $0430 \mathrm{HR}$ ) on the day after a drought cycle ended, leaf water potential $\left(\Psi_{\mathrm{pd}}\right)$ was determined on the leaf previously chosen for chlorophyll fluorescence measurements by using a pressure chamber (PMS Instruments, Corvallis, OR). At midday (1130 to $1300 \mathrm{HR}$ ) of the same day, transpiration and stomatal conductance $\left(g_{\mathrm{S}}\right)$ were measured with a steady-state porometer (LI-1600; LI-COR) on the leaf opposite to the one selected for determining $\Psi_{\text {pd }}$. After transpiration and $g_{\mathrm{s}}$ were taken, the leaf was excised and leaf midday water potential $\left(\Psi_{\mathrm{md}}\right)$ was determined. Water relations data from second drought cycle for LMP1 and UW2 were excluded from the statistical analysis because those plants inadvertently were irrigated before water relations data were recorded.

Relative water content. On 11 Nov. 2003, $81 \mathrm{~d}$ after the start of irrigation treatments, the experiment was ended. A fully expanded leaf was excised from each tree in each of the five blocks. Leaves were sealed in zipper storage bags, placed on ice, and transported to our laboratory $(1.2 \mathrm{~km})$. Leaf discs $\left(0.79 \mathrm{~cm}^{2}\right)$ were used to determine relative water content (RWC). A disc was excised from each leaf, and a fresh weight (FW) was obtained. Discs were rehydrated to obtain a saturated weight (SW) and then oven-dried to obtain a dry weight (DW). The formula $\mathrm{RWC}=[(\mathrm{FW}-$ $\mathrm{DW}) /(\mathrm{SW}-\mathrm{DW})] \times 100 \%$ was used to calculate RWC.

Specific leaf weight. A $0.79-\mathrm{cm}^{2}$ leaf disc was taken from the interveinal region opposite (opposite side of the midvein) the area where the leaf disc for RWC was taken. The disc was dried at $65{ }^{\circ} \mathrm{C}$ for $5 \mathrm{~d}$. Specific leaf weight (SLW) was calculated by dividing the DW of the disc by its area.

Foliar stable carbon isotope composition and carbon and nitrogen content. At the end of the experiment, the 10 youngest and fully expanded leaves from each plant were taken and dried immediately at $70{ }^{\circ} \mathrm{C}$ for $48 \mathrm{~h}$. Samples were finely ground to pass through a 40 mesh screen $(0.63 \mathrm{~mm}$ diam.). Two milligrams of dried homogeneous material was sub-sampled and used for ${ }^{13} \mathrm{C} /{ }^{12} \mathrm{C}, \mathrm{C}, \mathrm{N}$, and $\mathrm{C}: \mathrm{N}$ determinations. Duplicate samples from each treatment were analyzed at the Stable Isotope Laboratory at Augustana College, Biology Dept., Sioux Falls, SD.

Carbon isotope discrimination was calculated as $\Delta=\left(\delta_{\mathrm{a}}-\delta_{\mathrm{p}}\right) /\left(1+\delta_{\mathrm{p}}\right)$, where $\delta_{\mathrm{a}}$ and $\delta_{\mathrm{p}}$ are the isotopic compositions of air and foliar samples, respectively. The isotopic composition of air was set at $-8 \%$.

Final harvest. All plants were harvested destructively 11 Nov. 2003. Plant height, xylem diameter $2.5 \mathrm{~cm}$ above growing substrate level, total leaf surface area, and leaf, stem, and root DW were determined using procedures described for the initial harvest.

Data analysis. Data were analyzed using SAS/STAT software for windows Version 9.1 (SAS Institute, 2004). Analysis of variance procedures for the initial destructive harvest data, $\Psi_{\mathrm{pd}}, \Psi_{\mathrm{md}}, F_{\mathrm{v}} / F_{\mathrm{m}}, g_{\mathrm{S}}$, transpiration, were evaluated using a mixed model (VanLeeuwen et al., 2006). Differences in least-squares means were assessed at $P \leq$ 0.05 using the PDIFF option. Analyses included repeated measures (drought cycles) using compound symmetric (CS) covariance structure for the observations taken from the same tree (SAS Institute, 2004). The Kenward-Roger option was used to adjust standard error estimates and compute denominator df for the mixed model-based $F$ - and $t$-tests (SAS Institute, 2004).

Fixed effects included treatment, source, drought cycles, and all interactions. Blocks represented random factors, and trees served as the experimental unit. Correlations between $g_{\mathrm{S}}$ and transpiration were assessed using PROC CORR procedures of SAS software. To determine if there were differences between regression lines of $g_{\mathrm{S}}$ and transpiration, the PROC GLM procedure of SAS software was used.

\section{Results}

Before drought treatments started, shoot DW was the lowest in plants from Utah (UW2) (Table 1), and there were no differences in root DW, total plant DW (data not shown), plant height, or leaf area to xylem diameter ratio among sources (Table 1). Plants from Utah had the largest root to shoot DW ratio (Table 1). All plants completed three drought cycles, but the length of a drought cycle varied among each seed source because of differences in evapotranspiration (Table 1). Differences in evapotranspiration rates among seed sources were most likely due to unequal transpiration rates (Jones,
1998) because evaporation from pot surfaces is expected to be similar.

After $81 \mathrm{~d}$ of drought treatment, plant height was not different among sources or between treatments (Table 2). Plants from LMP5 had 5.7 times more total leaf area than plants from UW2 (Table 2). Bigtooth maples from LMP5 maintained both the highest leaf DW and leaf area/xylem diameter ratio among all plant sources (Table 2). Leaf area ratio (LAR) was highest in plants from LMP5, but there is no evidence that LAR was different between treatments (Table 2). Irrigation treatment did not impact specific leaf weight (SLW) or shoot DW of plants. Bigtooth maples from GM2 had among the highest SLW. Shoot DW was lowest in plants from UW2 (Table 2).

There were no differences among seed sources (first $P$ value) or between treatments (second $P$ value) for root DW $[P=0.8309$ (seed source), $P=0.9094$ (treatment)], stem DW $(P=0.1272, P=0.6075)$, total plant DW $(P=0.7151, P=0.8721)$, the root to shoot DW ratio $(P=0.1356, P=0.5339)$, and RWC $(P=0.2909, P=0.9644)$. The RWC of bigtooth maples from all sources averaged $57 \%$. The $F_{\mathrm{v}} / F_{\mathrm{m}}$ of plants averaged 0.64 and was not different among seed sources or drought treatments.

Carbon isotope discrimination varied from $-25.69 \%$ in plants from Dripping Springs State Park to $-27.03 \%$ in plants from Logan Canyon, but there was insufficient evidence to conclude that it differed among plant origins or between drought treatments (Table 3). Foliar carbon content was lowest in plants from Utah, and the $\mathrm{C}: \mathrm{N}$ ratio was similar among sources (Table 3).

Overall, plants subjected to drought stress had more negative $\Psi_{\mathrm{pd}}(-0.76 \pm 0.05 \mathrm{MPa})$ than the controls $(-0.64 \pm 0.05 \mathrm{MPa})(P=$ 0.0108 ). In contrast to plants from DS (Fig. 1A) and LMP1 and UW2, which did not show differences between drought-stressed and well-watered plants at their final drought

Table 3. Carbon isotope discrimination, foliar carbon content, and carbon to nitrogen ratio of five seed sources of bigtooth maple seedlings harvested after $81 \mathrm{~d}$ of drought treatment.

\begin{tabular}{llccc}
\hline Seed source & Tree & $\begin{array}{c}\text { Carbon isotopes } \\
\text { discrimination }(\%)\end{array}$ & $\begin{array}{c}\text { Foliar carbon(\% } \\
\text { dry wt.) }\end{array}$ & Carbon:nitrogen \\
\hline $\begin{array}{l}\text { Dripping Springs } \\
\quad \text { State Park, NM }\end{array}$ & DS & $-25.69 \mathrm{a}^{\mathrm{z}}$ & $43.8 \mathrm{ab}$ & $21.7 \mathrm{a}$ \\
$\begin{array}{l}\text { Guadalupe Mountains, } \\
\quad \text { Vanderpool, TX }\end{array}$ & GM2 & $-26.75 \mathrm{a}$ & $42.9 \mathrm{~b}$ & $23.1 \mathrm{a}$ \\
$\begin{array}{l}\text { Lost Maples State Natural } \\
\quad \text { Area, Salt Flat, TX }\end{array}$ & LMP1 & $-26.89 \mathrm{a}$ & $44.3 \mathrm{a}$ & $23.5 \mathrm{a}$ \\
$\begin{array}{l}\text { Lost Maples } \\
\quad \text { State Natural Area, }\end{array}$ & LMP5 & $-26.29 \mathrm{a}$ & $43.7 \mathrm{ab}$ & $24.6 \mathrm{a}$ \\
$\quad$ Salt Flat, TX & & & $23.2 \mathrm{a}$ \\
$\begin{array}{l}\text { Logan Canyon, } \\
\text { Cache County, UT }\end{array}$ & UW2 & $-27.03 \mathrm{a}$ & $40.5 \mathrm{c}$ & 23.2 \\
$\begin{array}{l}\text { Means } \\
\text { Significance }(P \text { values) }\end{array}$ & & -26.53 & 43.0 & 0.2667 \\
$\quad \begin{array}{l}\text { Irrigation treatment } \\
\text { Seed source }\end{array}$ & & 0.8992 & 0.7294 & 0.6008 \\
$\quad \begin{array}{l}\text { Seed source } \times \text { irrigation } \\
\text { treatment }\end{array}$ & & 0.4007 & 0.0046 & 0.2217 \\
\hline
\end{tabular}

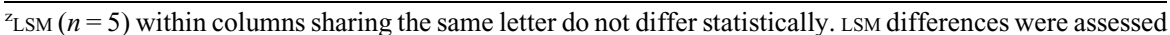
at $P \leq 0.05$ using the Proc Mixed/PDIFF option in SAS/STAT 9.1 (2004). 
cycle, plants from GM2 and LMP5 had treatment differences at the end of final drought cycle (Fig. 1B and C). Plants from UW2 had no differences in $\Psi_{\mathrm{pd}}$ between control and well-irrigated plants for drought cycles $1(P=0.6782)$ and $2(P=0.2679)$. Among drought-treated plants, those from LMP1 had the most negative $\Psi_{\text {pd }}(-1.05 \pm$ $0.09 \mathrm{MPa})$. Drought-treated plants had more negative $\Psi_{\mathrm{md}}(-1.84 \pm 0.1 \mathrm{MPa})$ than the controls $(-1.40 \pm 0.1 \mathrm{MPa})(P=0.0032)$ (Fig. 2), but $\Psi_{\mathrm{md}}$ did not differ between treatments at the third drought cycle $(P=0.0696)$ and among seed sources $(P=0.2294)$. Droughtstressed plants had the highest negative $\Psi_{\text {md }}$ at the end of the second drought cycle (Fig. 2). The magnitude of the difference in $\Psi_{\text {md }}$ among plant sources depended on the drought cycle $(P<0001)$, but the size of the difference in $\Psi_{\mathrm{md}}$ among sources did not depend on the irrigation treatment $(P=$ 0.0545).

Values of $g_{\mathrm{S}}$ were different among sources $(P=0.0042)$ but not between treatments $(P=0.3405$; Fig. 3A). Regardless of the treatment, averaged across drought cycles, plants from DS had the lowest transpiration rate $\left(2.32 \pm 0.23 \mathrm{mmol} \cdot \mathrm{m}^{-2} \cdot \mathrm{s}^{-1} ;\right.$ Fig. 3B $)$ and had among the lowest $g_{s}(52.1 \pm 7.7$ $\mathrm{mmol} \cdot \mathrm{m}^{-2} \cdot \mathrm{s}^{-1}$; Fig. 3A). For $g_{s}$, the only interactive effect was between source and drought cycle $(P<0.0001)$. The size of difference in transpiration among plant sources was contingent on the drought cycle $(P<$ $0.0001)$. Overall, transpiration was positively correlated with $g_{s}$ within treatment for both drought-stressed and well-watered plants (Fig. 4), but only one individual plant source (GM2) showed a correlation between transpiration and $g_{s}$ (Fig. 5).

\section{Discussion}

Plants designated as LMP5 invested more biomass in both leaves and shoots than the other plants, but we did not find treatment or plant source differences in biomass partitioning. These results are consistent with our earlier findings that biomass partitioning is not a drought adaptation mechanism for bigtooth maples (Bsoul et al., 2006). In contrast, initial differences in biomass allocation among seedlings (Table 1) suggest that carbon allocation might be an important seedling survival trait. However, biomass is allocated preferentially to leaves or roots to improve acquisition of limiting resources to balance growth (Shipley and Meziane, 2002). So, our results might indicate that either resources were nonlimiting or, in the face of limiting resources, bigtooth maples improved their efficiency of resource utilization. Efficient use of limited resources might explain why bigtooth maples have a broad ecological range.

High leaf area/xylem diameter ratio in plants designated as LMP5 suggests those plants maintained a high percentage of tissues that photosynthesize along with small but efficient tissues that regulate water transport (Balok and St. Hilaire, 2002). A reduction

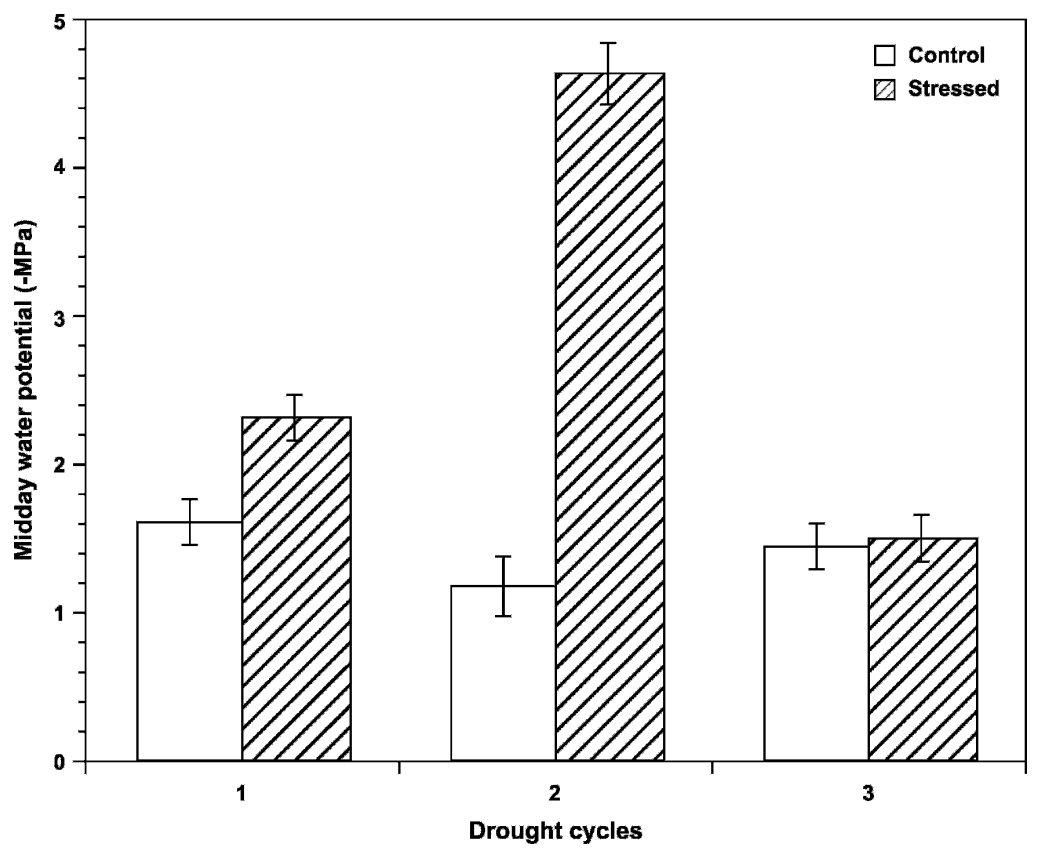

Fig. 2. Midday water potential of plants from five seed sources of $A$. grandidentatum (bigtooth maple) subjected to $81 \mathrm{~d}$ of cyclic drought. Data were pooled from DS, one seed source from Dripping Springs State Park, Las Cruces, NM; GM2, one seed source from the Guadalupe Mountains, Salt Flat, TX; LMP1 and LMP5, two seed sources from Lost Maples State Natural Area, Vanderpool, TX, and UW2, one seed source from a west-facing slope in Logan Canyon, Cache County, UT. Data for drought cycle 2 excludes data for LMP1 and UW2. Plants from each seed source completed three drought cycles. For drought cycles 1 and 3, each bar represents a mean \pm SE $(n=25)$. For drought cycle 2 , each bar represents a mean $\pm \operatorname{SE}(n=15)$.

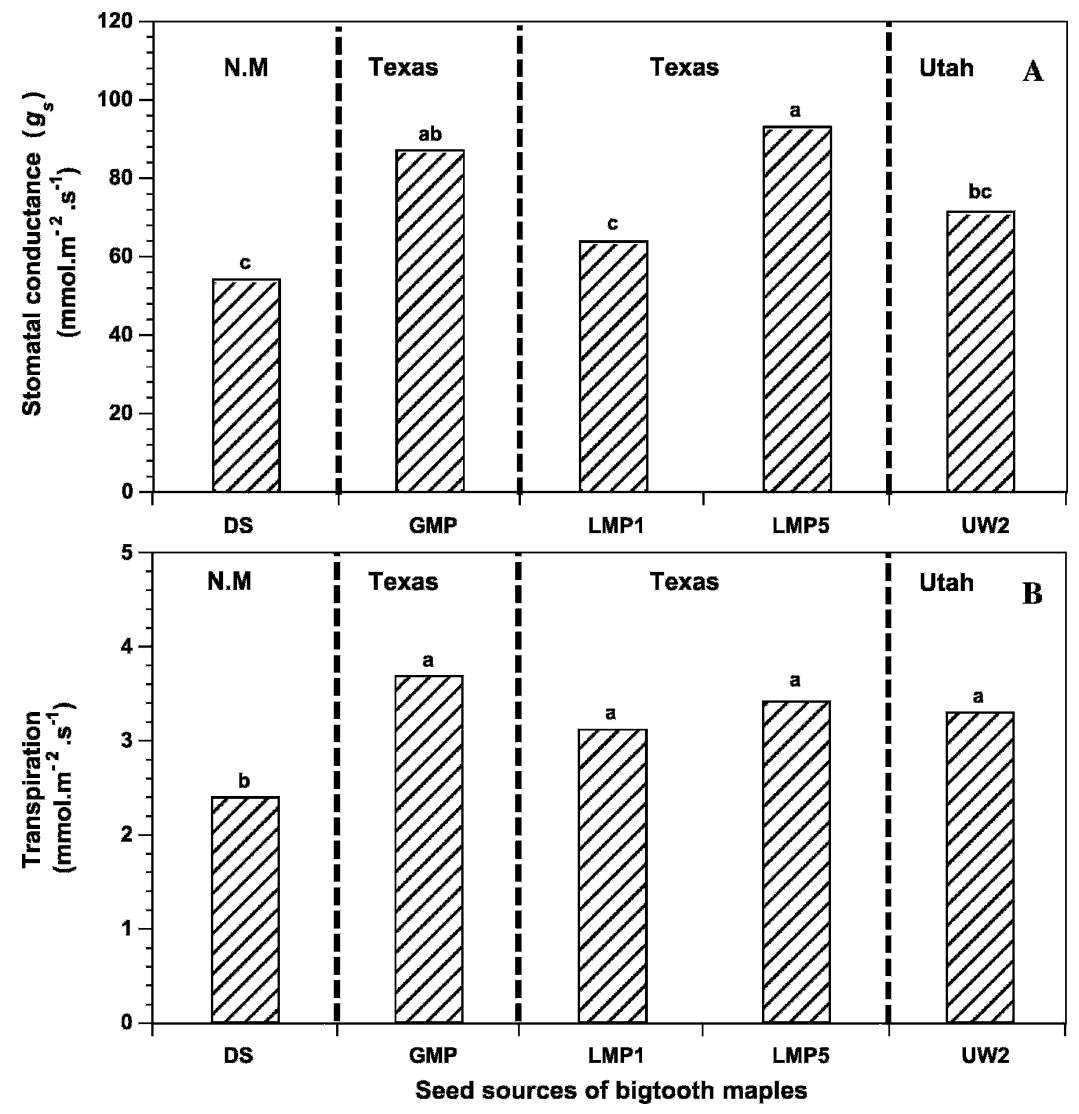

Fig. 3. Values of (A) stomatal conductance $\left(g_{\mathrm{S}}\right)$ and $(\mathbf{B})$ transpiration for A. grandidentatum (bigtooth maple) subjected to $81 \mathrm{~d}$ of cyclic drought, from DS, one seed source from Dripping Springs State Park, Las Cruces, NM; GM2, one tree from the Guadalupe Mountains, Salt Flat, TX; LMP1 and LMP5, two seed sources from Lost Maples State Natural Area, Vanderpool, TX; and UW2, one seed source from a west-facing slope in Logan Canyon, Cache County, UT. Plants from each seed source completed three drought cycles. Columns with same letters are not statistically different at $P=0.05$. 


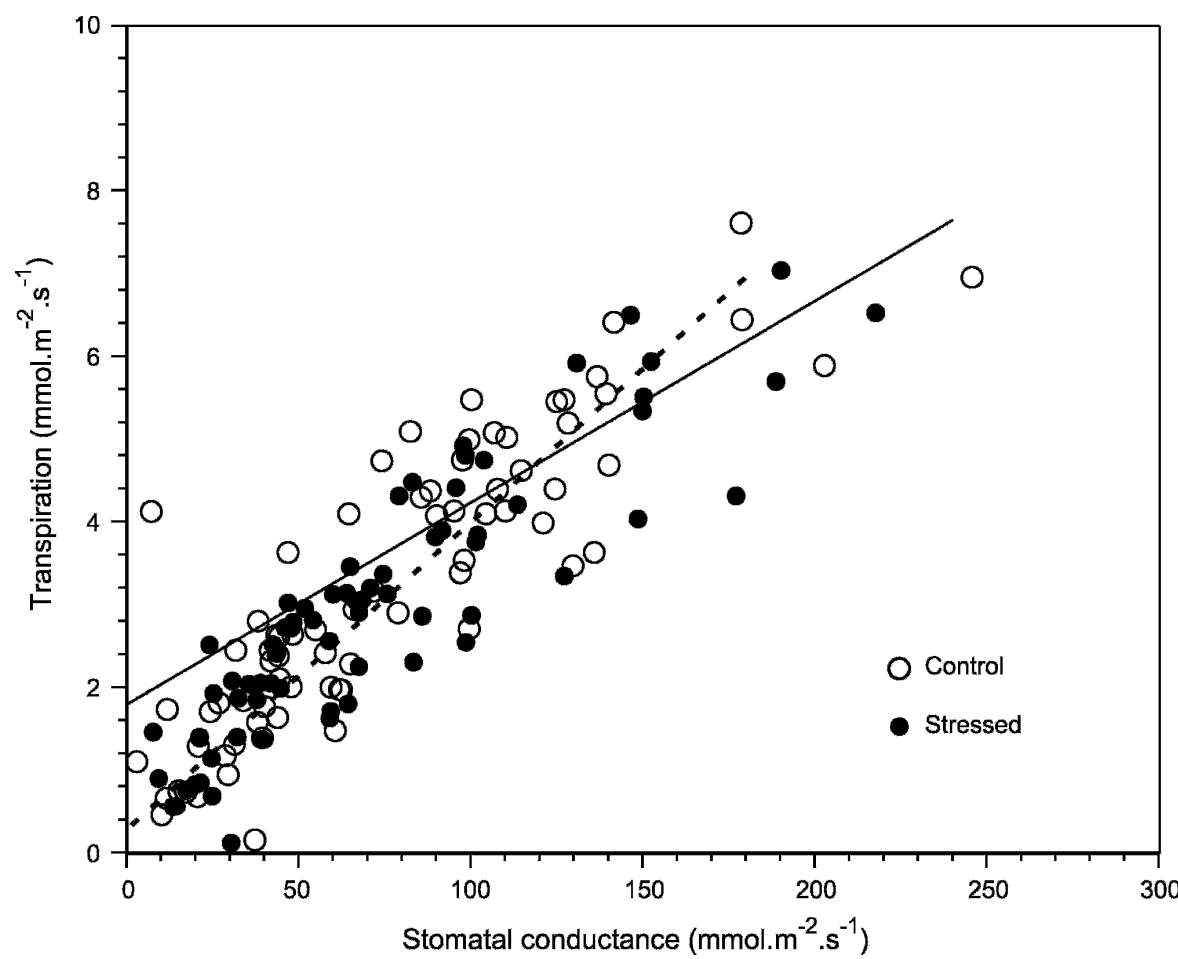

Fig. 4. Relationship between transpiration rate and stomatal conductance $\left(g_{\mathrm{S}}\right)$ for five seed sources (DS, one seed source from Dripping Springs State Park, Las Cruces, NM; GM2, one seed source from the Guadalupe Mountains, Salt Flat, TX; LMP1 and LMP5, two seed sources from Lost Maples State Natural Area, Vanderpool, TX, and UW2, one seed source from a west-facing slope in Logan Canyon, Cache County, UT) of $A$. grandidentatum (bigtooth maple) subjected to $81 \mathrm{~d}$ of cyclic drought. Solid and dashed lines represent linear regression lines for drought-stressed and control plants, respectively. Regression equation for controls: $y=0.0404 x+0.2203, r^{2}=0.759, P<0.0001$. Regression equation for stressed plants: $y=0.037 x+0.3173, r^{2}=0.801, P<0.0001$.

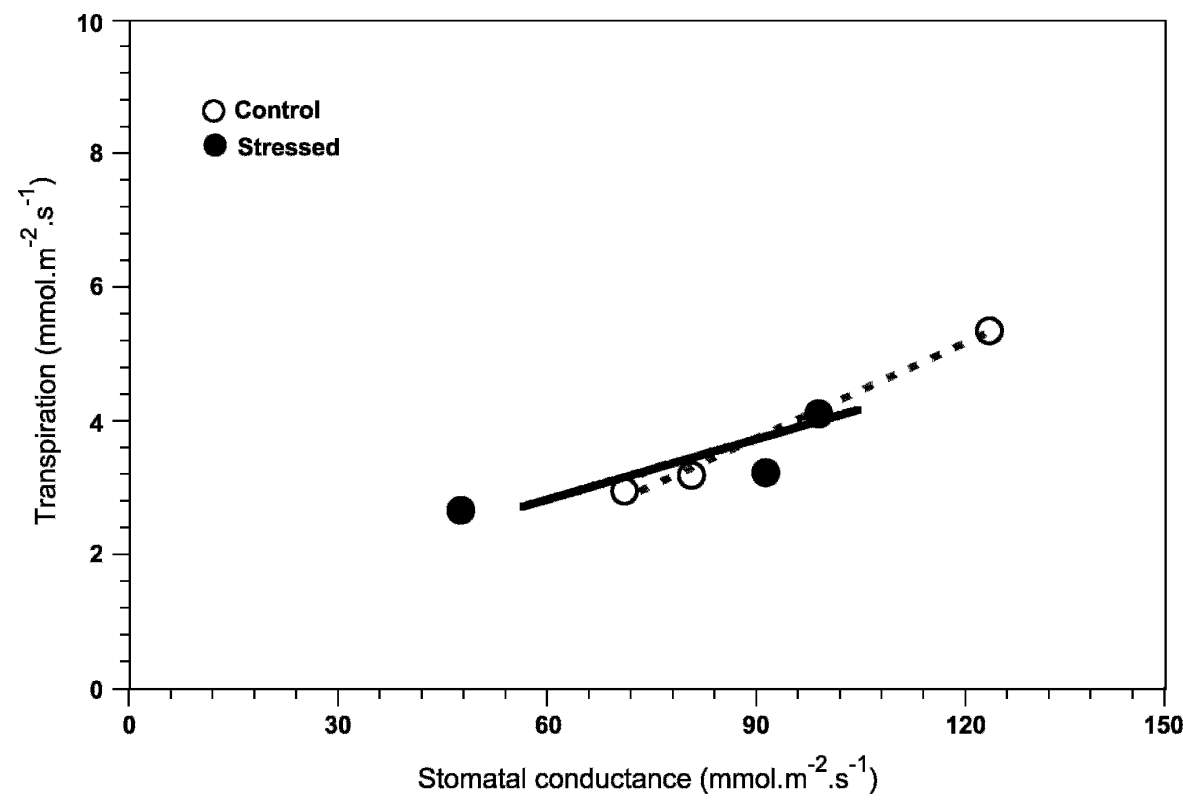

Fig. 5. Relationship between transpiration rate and stomatal conductance $\left(g_{\mathrm{S}}\right)$ for the GM2 seed source (one tree from the Guadalupe Mountains, Salt Flat, TX) of A. grandidentatum (bigtooth maple) subjected to $81 \mathrm{~d}$ of cyclic drought. Solid and dashed lines represent linear regression lines for droughtstressed and control plants, respectively. Regression equation for controls: Transpiration $=21.186 g_{\mathrm{S}}+$ 9.576, $r^{2}=0.993, P<0.052$. Regression equation for stressed plants: Transpiration $=35.714 g_{\mathrm{S}}-$ $48.429, r^{2}=0.999, P<0.021$.

in transpirational surface area is an important adaptation to drought in many plants (Feser et al., 2005). It is possible that LMP5 plants had smaller but more leaves than the other in LMP5 plants exposed to drought would enhance the landscape appeal of a plant. It is also possible that the high LAR of LMP5 plants will enhance plant growth because of increased carbon assimilation (Costa e Silva et al., 2004). Enhanced carbon assimilation would allow plants from LMP5 to be more competitive in areas exposed to episodic water scarcity.

Differences in SLW were confined to the origin of the seed sources and were not due to irrigation treatment. It is possible that differences in leaf density compensate for variations in SLW because these seed sources have consistently shown no differences in leaf thickness (Bsoul, et al., 2006). Plants tolerant to low moisture environments tend to have a higher SLW (Ashton and Berlyn, 1992; Witkowski and Lamont, 1991). So, bigtooth maples with constitutively high SLW, such as plants from GM2 and LMP5 (Table 2), might have a functional advantage in moisture-limited environments.

Leaf carbon isotope discrimination $(\Delta)$ is an integrated long-term measure of the factors affecting inward $\mathrm{CO}_{2}$ diffusion (leaf conductance) and $\mathrm{CO}_{2}$ consumption (photosynthetic rate) (Farquhar et al., 1989; Farquhar and Lloyd, 1993). Major and Johnsen (1996) cautioned that $\Delta$ should be used in conjunction with other physiological measures to unequivocally assess whether a species is resilient to drought. A strong negative correlation between $\Delta$ and water-use efficiency (WUE) has been reported for numerous crop and tree species (Farquhar et al., 1989; Zhang and Marshall, 1994). This prompted Bauerle et al. (2003) to use $\Delta$ as a surrogate for the WUE of red maples (Acer rubrum L.). However, the lack of plant source or irrigation treatment effects for $\Delta$ suggests that discrimination between ${ }^{12} \mathrm{C}$ and ${ }^{13} \mathrm{C}$ in bigtooth maple plants did not differ among plant sources or between drought-stressed and control plants. Our results are consistent with those of Bauerle et al. (2003), who found no differences in $\Delta$ between red maple provenances indigenous to xeric and mesic provenances.

The ratio of variable to maximal fluorescence $\left(F_{\mathrm{v}} / F_{\mathrm{m}}\right)$ might quantify the photochemical efficiency of PSII (Feser et al., 2005; Maxwell and Johnson, 2000). Under normal conditions, plants maintain $F_{\mathrm{v}} / F_{\mathrm{m}}$ close to 0.8 (Mir et al., 1998). Although the lack of an irrigation effect on $F_{\mathrm{v}} / F_{\mathrm{m}}$ suggests that drought-stressed bigtooth maples retained photosynthetic function close to the level of well-watered plants, Lamont and Lamont (2000) and Baz and Fernandez (2002) have suggested that $F_{\mathrm{v}} / F_{\mathrm{m}}$ might be relatively insensitive to drought stress. For example, in eight co-occurring arid species, $F_{\mathrm{v}} / F_{\mathrm{m}}$ was unaffected until RWC dropped $50 \%$ below turgor loss point $(\approx 1.5 \mathrm{MPa})$ (Lamont and Lamont, 2000). So, an irrigation effect on $F_{\mathrm{v}} / F_{\mathrm{m}}$ might be detected if the RWC of bigtooth maples declines below 57\%.

Sources of bigtooth maples differed in their ability to maintain low leaf $\Psi_{\mathrm{pd}}$ (Fig. 1). Compared with other seed sources, plants 
from the LMP1 seed source were least able to rehydrate their leaves before transpiration and photosynthesis started. In contrast, during midday periods of peak evaporative demand, leaf $\Psi$ was equivalent among plant sources. The $\Psi_{\mathrm{md}}$ of drought-stressed plants peaked at the second drought cycle and declined at the third drought cycle (Fig. 2). An increase in environmental stress decreases leaf water potential (Nilsen et al., 1983). However, if a young plant that is exposed to drought maintains low leaf water potential at the onset of the drought event, then the plant might be able to delay stress and limit severe stress damage at later development stages (Costa e Silva et al., 2004).

Generally, transpiration is proportional to $g_{\mathrm{S}}$ (Jones, 1998). As expected, both droughtstressed and well-watered plants had positive and linear relationships between transpiration and $g_{\mathrm{S}}$ (Fig. 4). Notwithstanding, only plants from GM2 had a strong relationship between $g_{\mathrm{S}}$ and transpiration in both drought-stressed and well-watered plants (Fig. 5). The low transpiration and $g_{\mathrm{s}}$ values for plants from DS (Fig. 3) indicate these plants were effective in reducing moisture loss during extended drought.

In summary, at the whole-plant level, biomass partitioning does not appear to play a very prominent role in the drought-adaptation strategy of bigtooth maples. At the foliar level, the high LAR in plants from LMP5 could enhance the resiliency of plants exposed to episodic drought in a managed landscape setting. Researchers may not be able to rely on $\Delta$ as a drought-tolerance screening method for bigtooth maple provenances. Under drought conditions, the relatively low $\Psi_{\text {pd }}$ in plants designated as LMP1 from the Lost Maples State Natural Area in Vanderpool, TX, and the low transpiration and $g_{\mathrm{s}}$ in plants from Dripping Springs State Park in Las Cruces, NM, might yield a competitive advantage for those plants. While all the selected plants in this experiment potentially will thrive in moisture limited environments, LMP1, LMP5, and DS plants might be particularly resilient to arid environments.

\section{Literature Cited}

Abrams, M.D. and A.K. Knapp. 1986. Seasonal water relations of three gallery forest hardwood species in northeast Kansas. For. Sci. 32:687696.

Abrams, M.D., M.E. Kubiske, and K.C. Steiner. 1990. Drought adaptations and responses in five genotypes of Fraxinus pennsylvanica Marsh.: photosynthesis, water relations and leaf morphology. Tree Physiol. 6:305-315.
Ashton, P.M.S. and G.P. Berlyn. 1992. Leaf adaptations of some Shorea species to sun and shade. New Phytol. 121:587-596.

Balok, C.A. and R. St. Hilaire. 2002. Drought responses among seven southwestern landscape tree taxa. J. Amer. Soc. Hort. Sci. 127:211-218.

Barker, P.A. 1974. The spectacular canyon maple. Utah Sci. 35:7-10.

Barker, P.A. 1975. Acer grandidentatum and its propagation. Proc. Int. Plant Prop. Soc. 25:3338 .

Batisse, M. 1994. The dry lands-arid regions. UNESCO Cour. (Jan): 1994.

Bauerle, W.L., T.H. Whitlow, T.L. Setter, T.L. Bauerle, and F.M. Vermeylen. 2003. Ecophysiology of Acer rubrum seedlings from contrasting hydrologic habitats: growth, gas exchange, tissue water relations, abscisic acid and carbon isotope discrimination. Tree Physiol. 23:841850 .

Baz, M. and R.T. Fernandez. 2002. Evaluating woody ornamentals for use in herbicide phytoremediation. J. Amer. Soc. Hort. Sci. 127:991-997.

Björkman, O. and B. Demming. 1987. Photon yield of $\mathrm{O}_{2}$ evolution chlorophyll fluorescence characteristics at $77 \mathrm{~K}$ among vascular plants of diverse origins. Planta 170:489-504.

Bsoul, E., R. St. Hilaire, and D. VanLeeuwen. 2006. Bigtooth maples exposed to asynchronous cyclic irrigation show provenance differences in drought adaptation mechanisms. J. Amer. Soc. Hort. Sci. 131:459-468.

Costa e Silva, F., A. Shvaleva, J.P. Maroco, M.H. Almeida, M.M. Chaves, and J.S. Pereira. 2004. Response to water stress in two Eucalyptus globulus clones differing in drought tolerance. Tree Physiol. 24:1165-1172.

Demming-Adams, B. and W.W. Adams, III. 1992. Photoprotection and other responses of plants to high light stress. Ann. Rev. Plant Physiol. Plant Mol. Biol. 43:599-626.

Dina, S.J., L.G. Klikoff, and M.B. Keddington. 1973. Seasonal water potential patterns in the mountain brush zone, Utah. Amer. Midland Naturalist 89:234-239.

Farquhar, G.D., J.R. Ehleringer, and K.T. Hubick. 1989. Carbon isotope discrimination and photosynthesis. Ann. Rev. Plant Physiol. Mol. Biol. 40:503-537.

Farquhar, G.D. and J. Lloyd. 1993. Carbon and oxygen isotopic effects in the exchange of carbon dioxide between terrestrial plants and the atmosphere, p. 47-70. In: Ehleringer, J.R., A.E. Hall, and G.D. Farquhar (eds.). Stable isotopes and plant carbon/water relations, Academic Press, San Diego, Calif.

Feser, C.F., R. St. Hilaire, and D. VanLeeuwen. 2005. Development of in-ground container plants of Mexican elders exposed to drought. HortScience 40:446-450.

Fort, C., M.L. Fauveau, F. Muller, P. Pabel, A. Granier, and E. Dreyer. 1997. Stomatal conductance, growth and root signaling in young oak seedlings subjected to partial soil drying. Tree Physiol. 17:282-289.
Handreck, K. and N. Black. 2002. Growing media for ornamental plants and turf. 3rd ed. Univ. New S. Wales Press, Sydney, Australia.

Hsiao, T.C. 1973. Plant responses to water stress. Ann. Rev. Plant Physiol. 24:519-570.

Jones, H.G. 1998. Stomatal control of photosynthesis and transpiration. J. Expt. Bot. 49:387398.

Lamont, B.B. and C. Lamont. 2000. Utilizable water in leaves of 8 arid species as derived from pressure-volume curves and chlorophyll fluorescence. Physiol. Plant. 110:46-71.

Major, J.E. and K.H. Johnsen. 1996. Family variation in photosynthesis of 22-year-old black spruce: a test of two models of physiological response to water stress. Can. J. For. Res. 26:1922-1933.

Maxwell, K. and G.N. Johnson. 2000. Chlorophyll fluorescence - a practical guide. J. Expt. Bot. 51:659-668.

Mir, N., M. Wendorf, R. Perez, and R.M. Beaudry. 1998. Chlorophyll fluorescence in relation to superficial scald development in apple. J. Amer. Soc. Hort. Sci. 123:887-892.

Nilsen, E.T., M.R. Sharifi, P.W. Rundel, W.M. Jarrell, and R.A. Virginia. 1983. Diurnal and seasonal water relations of the desert phreatophyte Prosopis glandulosa (honey mesquite) in the Sonoran Desert of California. Ecology 64:1381-1393.

Percival, G.C. and C.N. Sheriffs. 2002. Identification of drought-tolerant woody perennials using chlorophyll fluorescence. J. Aboricult. 28:215-222.

Peuke, A.D., C. Schraml, W. Hartung, and H. Rennenberg. 2002. Identification of droughtsensitive beech ecotypes by physiological parameters. New Phytol. 154:373-387.

SAS Institute, Inc. 2004. SAS/STAT 9.1 user's guide. SAS Institute, Inc., Cary, NC.

Shipley, B. and D. Meziane. 2002. The balancedgrowth hypothesis and the allometry of leaf and root biomass allocation. Funct. Ecol. 16:326331.

Simpson, B.J. and B.W. Hipp. 1993. Maples of the Southwest. Amer. Nurseryman 177:26-35.

St. Hilaire, R. 2002. Bigtooth maple: a plant that merits more use in southwestern landscapes. Landscape Plant News 13:10-11

Tankersley, B.E. 1981. Growth and propagation of Acer grandidentatum Nutt. MS Thesis, Texas A\&M Univ., College Station.

USDA Soil Conservation Service. 1980. Soil survey of Doña Ana County, New Mexico.

VanLeeuwen, D.M., R. St. Hilaire, and E.Y. Bsoul. 2006. Statistical analysis of mixed model factorial experiments with missing factor combinations: the case of asynchronous cyclic drought data. J. Amer. Soc. Hort. Sci. 131:201-208.

Witkowski, E.T.F. and B.B. Lamont. 1991. Leaf specific mass confounds leaf density and thickness. Oecologia 88:486-493.

Zhang, J. and J.D. Marshall. 1994. Population differences in water-use efficiency of wellwatered and water-stressed western larch seedlings. Can. J. For. Res. 24:92-99. 